\title{
A Purpose Driven Life: My Journey from Student to Teacher Chad Walton
}

$\mathrm{I}$

am 37 years old and was sentenced to life without parole at the age of 19 .

The judge told me that just because I was going to do the rest of my life in prison, it did not mean that my life was over. I still had the ability to be a decent man. At that point in my life I had no idea what he was talking about. I figured my life was indeed over and the only thing the future held for me was a lot of hard time in prison.

I arrived at the Washington State Penitentiary in Walla Walla eight days before my twentieth birthday. I had no idea what life had in store for me there. The only thing that I could think about was how I was going to survive. Looking back, I see that when life is at its hardest your needs are boiled down to necessity. Primal instincts set in and self-preservation is an easy purpose to focus on. When you are twenty years old your ideas about how best to go about securing your existence in a place where the only thing that seems to be respected is violence can easily lead you down a very hard road. I traveled a long way down that road before the words the sentencing judge spoke could set in. To say I found education in a school of hard-knocks is fitting.

Education provides incarcerated people with feelings of self-worth and confidence. Ultimately, education leads prisoners to want to become better people. For example, I came to prison at the age of nineteen with almost no education, but I possessed the will to learn. I enrolled in the GED program at Washington State Penitentiary and took education seriously for the first time in my life. Once I began to understand the information being taught, my confidence began to soar. Before I knew it, I was taking tests as fast as I was allowed and passing them with little trouble. This created a drive in me to want to achieve more and to focus on something positive for the first time in my life. In fact, upon completing my GED I signed up to take a college level psychology course. I began to understand that with the right amount of drive and effort, I could set positive goals and become a success story. As a result of being afforded the opportunity to educate myself in prison, I realized that I had what it took to become a contributing member of society by becoming a better person in prison.

Shortly after completing my first college course at the state penitentiary with a B grade, a 2010 bill was passed in Washington State that significantly cut funding for prison education. Opportunities for education beyond obtaining a GED and taking court ordered classes such as Anger Management 
and Victims Awareness became nearly obsolete. Without the opportunity to obtain positive forms of education, prisoners had to seek education elsewhere. Incarcerated men are extremely intelligent when they put their minds to figuring out problems. I have seen prisoners light their weed with three pieces of pencil lead and an electrical socket when they did not have a match. However, is this the type of education that you want incarcerated men bringing back to the community? Negative education leads to negative consequences in life. For instance, it was not long before I was testing my new found knowledge obtained through the prison's best criminals, when positive education was no longer available to me. Ultimately, this led to a lot of time in segregation. Prisoners are hungry for education and if positive education is unavailable, they will fall back on what they know and are comfortable with - criminal activity.

Fast forward nineteen years and we get to where I am today. My ideas about what my purpose in this life is have taken many forms and in the prison environment your options are limited, although I have tried not to look at it like that. I believe a man must do the best he can with what he has, and not to waste time dwelling on all the things he does not possess or what he cannot do because of his circumstances. I have spent a lot of time reading books and trying to understand new ideas so that I can better understand myself and elevate my level of thought. For a long time, my purpose was education through which I gained the self-confidence required to begin to share my ideas with others.

My purpose slowly began to change from self-education to educating others. I began by teaching younger prisoners about their heritage and culture through the pre-Christian religion known as Asatru. When I became aware of the positive sense of self this helped to generate as we learned what our ancestors had gone through, it became my purpose in life to do my part to carry-on their teachings. I believe that it is impossible to know where you are going until you know where you have been. I also believe that one has to possess a solid foundation of who you are before being able to build a personal life philosophy of your own. Confidence comes in knowing who you are and what you want for your future. My goal is to give younger prisoners a reason to go back into the community and to help bring something positive into their lives, which requires moving away from the thoughts and behaviours that led them to prison in the first place. Without a change of ideas there will never be a change in behaviour. 
I eventually came across the T.E.A.C.H. (Taking Education and Creating History) program here at the Clallam Bay Correctional Center (CBCC). T.E.A.C.H. is run by a diverse board of directors made up of prisoners and offers classes so that prisoners can work toward an AA degree. I found T.E.A.C.H. while working as a janitor on the school floor. I noticed that there was a room set up for prisoners to teach classes to other prisoners. I would slide by the door with the dust mop and hear math, sociology, writing, and many other classes being taught. This was not a place just to go and hangout, it was school with the same expectations that any other school would have of its students. In fact, the expectations were often a lot higher because the prisoner that was teaching the class had put his own time into the course and was typically a well-respected member of the prison community. To be disruptive in class is considered a sign of disrespect, which is not tolerated among incarcerated populations. Prisoners are expected to come to class voluntarily in order to better themselves, not because they are being made to attend by prison authorities. From the teacher's perspective, you better come ready to do the work because there will be work to do.

I was astounded by what I witnessed and I knew a lot of the prisoners running the program. I approached the President and Vice-President of the T.E.A.C.H. program and asked if I could teach a course on the History of the Vikings. I was told to submit the course content. I had already been teaching a course to the Asatru group at CBCC, which I proposed to the T.E.A.C.H. Board. They accepted and, in time, I also joined the T.E.A.C.H. Board.

The amount of work that it has taken to get this program up and running is beyond most people's imagination. To say that it is impressive is an understatement. Members of every race came together in an effort to better themselves within these walls. For those of you that have never had any experience with prisons this may not seem like a big deal, but let me assure you that different races working together in prison is uncommon to say the least. T.E.A.C.H. allows different groups to work together to teach their cultural values to anyone that wishes to learn about them. More than that, it offers prisoners that would otherwise have few opportunities to go to school the ability to learn. Being able to attain an education will help prisoners to make better decisions and to successfully reintegrate upon release. In this way, education can help to foster a new purpose in life - to give back to the community some of what was taken through criminality. Henry David Thoreau (2006) said that if he was a spider that was contained in the corner 
of an attic, his world would still be vast so long as he kept his thoughts about him. Through T.E.A.C.H. a vast new world is possible and it makes this corner of the attic seem to shine with a new light of possibility.

Over the years I have spent in prison, I have educated myself enough to begin to understand the importance of educating others. For young prisoners, there is no better place for positive education to originate than the older prisoners they look up to as peers. If older prisoners emphasize the importance of a higher education, the younger prisoners are more likely to listen. These young prisoners show up to class and pay attention for the full three-hour session and are excited to come back at the next opportunity. Through this privately funded organization, prisoners are able to give back to the community by facilitating courses that will help younger prisoners on their path to success. Eventually most of the T.E.A.C.H. students will be released back into the community, taking with them the education and work ethic that they have developed from working with incarcerated facilitators. The prisoners that facilitate courses have high expectations of their students, which in return creates a sense of responsibility in them. In short, I am fortunate to be a part of the T.E.A.C.H. program here at CBCC and to help educate my fellow prisoners; this work simultaneously gives meaning to my life, as well as the lives of my students.

Education affords people in prison the opportunity to understand that they are capable of becoming successful and of making a difference in their lives, along with their communities. I gained a sense of confidence and self-worth from education, and now feel that I am moving in the right direction in life. Without T.E.A.C.H., I would have continued to educate myself in a negative manner. Instead of standing in front of a class and teaching about the importance of European culture through the history of the Vikings, I would likely be standing in the prison yard teaching people how to be smarter about breaking rules. These are the things that we need to take into account when we are considering the importance of education in prison. The public has a choice to spend the money that is needed to educate the nation's incarcerated people or they can spend that money on housing them in prison for the rest of their lives. Speaking as a prisoner with nineteen years of incarceration under my belt, I can tell you that without actively working to change the minds of prisoners, you will never be able to change their behaviour. If we believe that people are redeemable, it is our responsibility to help them on the road to redemption 
by educating them about how their choices are going to affect their lives and the lives of others.

Many people in America today have a hard time seeing the value and meaning of education in a prison setting. With the economy in the dumps there is hardly funding for educating our youth, much less our incarcerated youth. Thus, when it comes to spending money on prisoners, education is the last thing that comes to mind. Some people fail to understand that it costs this nation more money to deny incarcerated people a means to educate themselves. Without teaching the criminalized that there is a better way to achieve their goals, they will continue to rely on crime, which will cost millions in tax payer dollars. If prisoners were afforded the opportunity of higher education while incarcerated, the recidivism rate would drop dramatically, saving the nation money in the long run. Although some might deny the value of providing education in a prison setting, I argue that there is hardly a better place to demonstrate its value and meaning for those involved.

\section{REFERENCES}

Thoreau, Henry D. (2006) Walden; or, Life in the Woods, Boston: Ticknor and Fields.

\section{ABOUT THE AUTHOR}

Chad Walton is incarcerated in the Clallam Bay Correctional Center in Washington State. Sentenced to life without parole at the age of 19, he is currently 37 years old. He spends much of his time in prison reading, studying, and enrolling in different educational and vocational training courses. He has also become a teacher and is currently facilitating a course on the History of the Vikings. He can be contacted at:

Chad Walton

$$
\text { \#783859 J-B-24 }
$$

Clallam Bay Correction Center 1830 Eagle Crest Way

Clallam Bay, Washington 98326

USA 